OPEN ACCESS

Edited by:

Gavin L. Simpson,

University of Regina, Canada

Reviewed by:

Jennifer Korosi,

York University, Canada

Maarten Blaauw,

Queen's University Belfast,

United Kingdom

Keely Mills,

British Geological Survey (BGS),

United Kingdom

*Correspondence:

Jesse C. Vermaire

jesse.vermaire@carleton.ca

Specialty section:

This article was submitted to

Paleoecology,

a section of the journal

Frontiers in Ecology and Evolution

Received: 10 August 2017 Accepted: 09 November 2017 Published: 23 November 2017

Citation:

Vermaire JC, Taranu ZE,

MacDonald GK, Velghe K, Bennett EM and Gregory-Eaves I (2017) Extrinsic vs. Intrinsic Regimes Shifts in Shallow Lakes: Long-Term Response of Cyanobacterial Blooms to Historical Catchment Phosphorus

Loading and Climate Warming.

Front. Ecol. Evol. 5:146.

doi: 10.3389/fevo.2017.00146

\section{Extrinsic vs. Intrinsic Regimes Shifts in Shallow Lakes: Long-Term Response of Cyanobacterial Blooms to Historical Catchment Phosphorus Loading and Climate Warming}

\author{
Jesse C. Vermaire ${ }^{1 *}$, Zofia E. Taranu ${ }^{2}$, Graham K. MacDonald ${ }^{3}$, Katherine Velghe ${ }^{4}$, \\ Elena M. Bennett ${ }^{5}$ and Irene Gregory-Eaves ${ }^{6}$ \\ ${ }^{1}$ Department of Geography and Environmental Studies and Institute of Environmental Science, Carleton University, Ottawa, \\ ON, Canada, ${ }^{2}$ Department of Biology, University of Ottawa, Ottawa, ON, Canada, ${ }^{3}$ Department of Geography, McGill \\ University, Montréal, QC, Canada, ${ }^{4}$ Department of Biology, Université du Québec à Montréal, Montréal, QC, Canada, \\ ${ }^{5}$ Department of Natural Resource Sciences and McGill School of Environment, McGill University, Ste Anne de Bellevue, QC, \\ Canada, ${ }^{6}$ Department of Biology, McGill University, Montréal, QC, Canada
}

To evaluate the relative influence of intrinsic and extrinsic factors on ecosystem dynamics and regime shifts, we examined the algal response to historical catchment phosphorus loading from two shallow lakes located in Quebec, Canada. Roxton Pond is a eutrophic shallow lake with submerged macrophytes, and Lake Petit Saint-François (PSF) is a hypereutrophic shallow lake with no submerged macrophytes. Specifically, we inferred past cyanobacteria dynamics using pigment analyses, and tested whether the most parsimonious response model for cyanobacteria dynamics was congruent with the response model for phosphorus loading to the catchment. For both lakes, we found that an abrupt increase in cyanobacteria concentration lagged behind the initial increases in agricultural phosphorus use in the catchment as well as climate warming by over a decade. The delayed cyanobacterial response to these external drivers, observed in both lakes, suggests that intrinsic factors more than likely played important roles in ecosystem dynamics. These results show that cyanobacteria dominance in shallow lakes can be brought on by intrinsic responses to catchment phosphorus loading, climate warming, or both, but the timing depends on the antecedent conditions and the magnitude of the external forcing.

Keywords: paleolimnology, cyanobacteria, shallow lakes, regime shift, phosphorus, diatoms, eutrophication

\section{INTRODUCTION}

Regime shifts are abrupt changes between two or more ecological states, each characterized by their own dynamics (Holling, 1973; Scheffer et al., 2009). Regime shifts have been described for many ecosystems, including the transition from forest to desert (Foley et al., 2003), the replacement of coral reefs by brown algae (deYoung et al., 2008) and shifts between clear and turbid water states in shallow lakes (Scheffer, 2004). Consideration of regime shifts adds greater complexity to ecosystem management and restoration because regime shifts are difficult to predict, hard to reverse, can 
result in time lags between environmental stressor and ecosystem change, and often involve a transformation to an undesirable state (Groffman et al., 2006). Consequently, there is much interest in understanding how natural systems respond to environmental change, including the ecosystem's ability to buffer the impacts of environmental stressors (Biggs et al., 2009; Scheffer et al., 2009).

Changes in primary production in shallow lake ecosystems are one of the better-described examples of regime shifts (Scheffer, 2004). Ecosystem models have shown that changes in external drivers, such as phosphorus loading, can shift shallow lakes from a macrophyte-dominated, clear-water state to a cyanobacteriadominated, turbid-water state (Scheffer, 2004). Compared to other ecosystems, the relatively well-defined boundaries of shallow lakes have made them an ideal system to examine theories related to regime shifts (Scheffer, 1990; Jeppesen et al., 1999; Bayley et al., 2007). Furthermore, we can infer the ecological dynamics of shallow lakes over long time-scales (decades to millennia) by examining their sediment record, which contain subfossils of numerous organisms (Karst and Smol, 2000; McGowan et al., 2005; Smol et al., 2005; Sayer et al., 2010; Wang et al., 2012). Given that regime shifts are infrequent events and can take many years to develop (Carpenter and Brock, 2006), long-term monitoring data that capture such events are rare. As a result, paleolimnological investigations have provided much-needed time-series data for understanding ecological transitions (e.g., Smol et al., 2005; Sayer et al., 2010; Wang et al., 2012; Randsalu-Wendrup et al., 2016).

A common thread among recent studies of regime shifts is the idea that an ecosystem may experience nonlinear dynamics in response to either extrinsic or intrinsic processes (Seddon et al., 2014). An extrinsic shift will occur in response to an abrupt change in an environmental driver, similar to the "driver threshold" scenario outlined in Andersen et al. (2009) and Randsalu-Wendrup et al. (2016). Intrinsic shifts, on the other hand, are the product of crossing an internal threshold in response to gradual environmental change (Williams et al., 2011), similar to the "state threshold" or "state-hysteresis" models of regime shifts outlined in Andersen et al. (2009) and RandsaluWendrup et al. (2016).

In this study, we examined long-term algal dynamics (diatoms and cyanobacteria) in two shallow lakes and assessed if the algal dynamics in these systems have been stable over time or have undergone abrupt shifts in community composition (diatoms) or concentration (cyanobacteria). Diatom community assemblages provide an indication of nutrient enrichment (Hall and Smol, 1992) and broad shifts in aquatic plant biomass (Vermaire and Gregory-Eaves, 2008; Vermaire et al., 2012) whereas the concentration echinenone pigment is associated with cyanobacteria biomass (Leavitt and Hodgson, 2001). In addition, we analyzed the long-term response of the sedimentary cyanobacteria timeseries to increased catchment phosphorus loading from agricultural activities during the twentieth century and warmer temperatures. Specifically, evaluated whether a shift in cyanobacteria concentration occurred, and if so, was the shift the result of an abrupt ecological transition paralleled by a rapid, nonlinear change in the environmental driver (extrinsic process) or an abrupt response to a gradual, linear change in the driver (intrinsic process). Typically, studies of regime shifts in lake ecosystems have focused on epilimnetic total phosphorus (TP) as a measure of nutrient loading because of the ease of sampling and the availability of data (e.g., Bachmann et al., 2002; McGowan et al., 2005; Bayley et al., 2007). However, epilimnetic TP represents an integration of phosphorus from both external and internal sources and can rapidly change during regime shifts as a result of internal loading from sediments (Scheffer, 2004; Carpenter, 2005). As the focus of this study is on local extrinsic drivers of regime change we instead estimated a historical $\mathrm{P}$ loading to the watershed from land-use activities as a measure of a local external stress on the lake ecosystems.

\section{METHODS}

\section{Study Sites}

Lake Petit Saint-François (PSF; latitude 45.54, longitude -72.04) and Roxton Pond (latitude 45.47, longitude -72.66) are small (surface area $<200 \mathrm{ha}$ ), shallow (mean depth $\leq 3.1 \mathrm{~m}$ ) lakes located in the Eastern Townships region of Quebec, Canada. The Eastern Townships are an important tourism and recreation area located approximately $150 \mathrm{~km}$ southeast of Montreal, south of the St. Lawrence River, and north of the U.S. states of Vermont, New Hampshire, and Maine. Although there has been considerable agricultural abandonment and forest regrowth in parts of this region during the twentieth century, agriculture has been a major land use over the last $\sim 100$ years in the catchments of our study lakes (MacDonald and Bennett, 2009). The study lakes cover a eutrophic to hypereutrophic range of contemporary mean summer $\mathrm{TP}$ and phytoplankton concentrations, measured as chlorophyll $a(\mathrm{Chl} a)$. PSF Lake is presently hypereutrophic $(2009-2015$ mean TP $=216 \mu \mathrm{g} / \mathrm{L}$, and Chl $a=71 \mu \mathrm{g} / \mathrm{L}$; http://www.mddelcc.gouv.qc.ca/eau/rsvl/index. asp) and contains almost no submerged macrophytes, whereas Roxton Pond is eutrophic (2004-2015 mean TP $=39 \mu \mathrm{g} / \mathrm{L}$, and Chl $a=28 \mu \mathrm{g} / \mathrm{L}$; http://www.mddelcc.gouv.qc.ca/eau/rsvl/ index.asp) and still contained dense and widespread submerged macrophyte beds at the time of sampling. Cyanobacteria are an important part of the contemporary phytoplankton community in both of these lakes and elevated levels of microcystin toxin have been reported (Giani et al., 2005; Lévesque et al., 2014; Monchamp et al., 2014). Both study lakes have had their water levels artificially raised by small dams constructed in the early to mid-twentieth century. The height of the dams for lakes PSF and Roxton are $1.6 \mathrm{~m}$ (constructed in 1966) and $4.7 \mathrm{~m}$ (constructed in 1920), respectively (Quebec Hydrology Expertise Centre; http:// www.cehq.gouv.qc.ca/index.asp).

\section{Field and Laboratory Methods}

Sediment cores for diatom, zooplankton, and pigment analyses were collected from near the deepest region of each lake in the summer of 2008 ( $1.9 \mathrm{~m}$ in PSF and $5.5 \mathrm{~m}$ in Roxton). A $78 \mathrm{~cm}$ long sediment core was obtained from PSF using a push corer that was then extruded at $1 \mathrm{~cm}$ intervals in the field to a depth $(\sim 15 \mathrm{~cm})$ where the sediment was sufficiently consolidated to allow shipment back to the laboratory. In the laboratory, the PSF 
sediment core was split longitudinally and half the core was subsampled at $1 \mathrm{~cm}$ intervals for analysis, the other half was archived. A $39 \mathrm{~cm}$ long sediment core was obtained from Roxton Pond using a Glew core (Glew, 1989), which was extruded in the field at $0.5 \mathrm{~cm}$ intervals. The sub-sampled sediment was kept at $4^{\circ} \mathrm{C}$ in the dark until processed. The chronologies for the sediment cores were determined through radiometric ${ }^{210} \mathrm{~Pb}$ and ${ }^{137} \mathrm{Cs}$ dating at McGill University using a Canberra gamma spectrometer with the constant rate of supply model (Appleby, 2001).

Diatom slide preparation and enumeration followed standard procedures (Battarbee et al., 2001). Briefly, samples were first treated with $10 \% \mathrm{HCl}$ to remove any carbonates, rinsed several times with deionized water and then treated with boiling $\mathrm{H}_{2} \mathrm{O}_{2}$ to remove organics. Samples were subsequently rinsed with deionized water seven times, plated onto coverslips, and mounted with Zrax. For each sample, a minimum of 400 diatom valves were counted and identified following Cumming et al. (1995), Fallu et al. (2000), and Krammer and Lange-Bertalot (2004).

To characterize the littoral zooplankton assemblage, we quantified the proportion of chydorid subfossils as a function of all cladoceran carapace subfossils preserved in each sediment interval following the methods described in Korhola and Rautio (2001). The community composition of cladocera in the study region is driven largely by nutrient concentration and macrophyte abundance (Velghe et al., 2012). For PSF Lake, the chydorid data were previously published in study of a shorter sediment core (Richard Albert et al., 2010). We matched up the shorter sediment record from PSF Lake to data from the longer core using the ${ }^{210} \mathrm{~Pb}$-derived age models from each core.

We conducted pigment analyses to quantify the concentration of the cyanobacteria associated pigment echinenone following standard methods in paleolimnology (Leavitt and Hodgson, 2001). Briefly, to extract pigments from the sediments, we placed approximately $0.1 \mathrm{~g}$ of freshly freeze-dried sediment into $100 \%$ acetone, purged this sample with Argon, and stored it at $-20^{\circ} \mathrm{C}$ for $24 \mathrm{~h}$. The extract was subsequently filtered through a PTFE $0.2 \mu \mathrm{m}$ filter and then injected into a Waters, high performance liquid chromatography (HPLC) system. Pigments were analyzed following the protocol of Zapata et al. (2000) and quantified using external standards purchased from DHI (Denmark).

\section{Historical Land Use and Climate Data}

As a proxy for local external stress on the lake ecosystems due to agricultural activities, we calculated phosphorus balances using county-level agricultural census data (counties are called "census division" in more recent censuses), which are available at 10-year intervals from 1871 to 2001 (e.g., decadal resolution of land-use change). Our phosphorus balances (detailed in MacDonald and Bennett, 2009) account for the net-phosphorus inputs to cropland soils via the application of livestock manure and mineral fertilizers after subtracting the phosphorus removed from cropland soils by harvested crops annually. These phosphorus balances provide an areal estimate of the magnitude of phosphorus accumulation in cropland soils $\left(\mathrm{kg} \mathrm{ha}^{-1}\right.$ year $\left.^{-1}\right)$ and provide a long-term record of changing land use and management practices that could alter catchment soil phosphorus.
We calculated an approximate "phosphorus load index" (P load index) in $\mathrm{g} \mathrm{m}^{-3}$ year ${ }^{-1}$ by multiplying the areal phosphorus balances by the catchment area and scaling this measure by lake volume. Lake volume was estimated from bathymetric maps and we calculated the historical phosphorus load index using both estimates of modern lake volume and pre-dam estimates of lake volume as appropriate. The phosphorus load index is only indicative of changes in agricultural phosphorus management, and does not account for other anthropogenic sources of phosphorus (e.g., residential septic tanks systems); however, our analysis of aerial photographs from approximately 1945 to present indicates that agriculture has been the predominant land use type in the catchments of the study lakes. In addition, the counties are substantially larger than the catchments of the study lakes, but our earlier studies have shown strong relationships between the historical census land use records, catchment soil phosphorus concentrations, and lake eutrophication trends (e.g., MacDonald and Bennett, 2009; Richard Albert et al., 2010; Shaw Chraibi et al., 2011), suggesting that census data can provide a reliable historical estimate of land-use intensity and phosphorus loading in this region.

In addition to excessive nutrient loading, climate warming has also been shown to be an important predictor of cyanobacteria dynamics in lakes (Taranu et al., 2015). To examine if changes in mean annual temperature over the last century were related to changes in cyanobacteria concentrations in our study lakes we used the adjusted and homogenized climate data from the Brome, Quebec, weather station (latitude 45.18; longitude -72.57; altitude $206 \mathrm{~m}$; sampling years 1891-2013; Vincent et al., 2012). The Brome weather station was the closest weather station to our two study sites (approximately $75 \mathrm{~km}$ from PSF and $40 \mathrm{~km}$ from Roxton Pond) where adjusted and homogenized climate data was available over a similar time period to our phosphorus load index estimates ( last 100 years).

\section{Numerical Analyses}

To examine if PSF and Roxton have undergone significant shifts in their algal assemblage or concentrations we employed clustering analyses constrained by time. Stratigraphically constrained cluster analysis was applied using CONISS (Grimm, 1987) to examine clustering in the diatom assemblages using the rioja package (Juggins, 2016) in $\mathrm{R}$ ( $\mathrm{R}$ Development Core Team, 2016). For the higher temporal resolution cyanobacterial pigment data, we tested whether PSF and Roxton Pond had statistically significant groupings in cyanobacteria concentrations over the sediment record using a regression tree approach constrained by time (De'ath, 2002) using the rpart package and MVPARTwrap wrapper function in the $\mathrm{R}$ statistical program (Ouellette and Legendre, 2013; Therneau et al., 2014; R Development Core Team, 2016). The cross-validation procedure available in MVPARTwrap helped determine the best number of statistically significant groupings (Legendre and Legendre, 2012). As recommended by De'ath (2002), the model containing the fewest number of groups within one standard error of the optimal model was selected. We then used an ANOVA and a post-hoc Tukey test to examine if the different groups identified in the temporally-constrained regression tree analyses had 
significantly different mean echinenone concentrations. If the regression tree groups did not have statistically different mean echinenone concentrations, we considered them part of the same cyanobacterial group of the lake whereas if the mean echinenone was significantly different we considered this period as a different cyanobacterial group for these shallow lakes.

Once historical cyanobacterial groups were identified based on the regression tree, we quantified the trends in echinenone concentration across the transition corresponding to the timing of the catchment P load index (from 1871 to 2001) and the observational temperature record by fitting linear, unimodal, threshold and sigmoidal models to both the environment (catchment $\mathrm{P}$ load index and mean annual temperature) and response (echinenone concentration) series using generalized nonlinear least squares regression (Seddon et al., 2014). The best model for each variable was then identified using the Akaike Information Criterion (AIC). To evaluate the relative importance of intrinsic vs. extrinsic dynamics over this transition

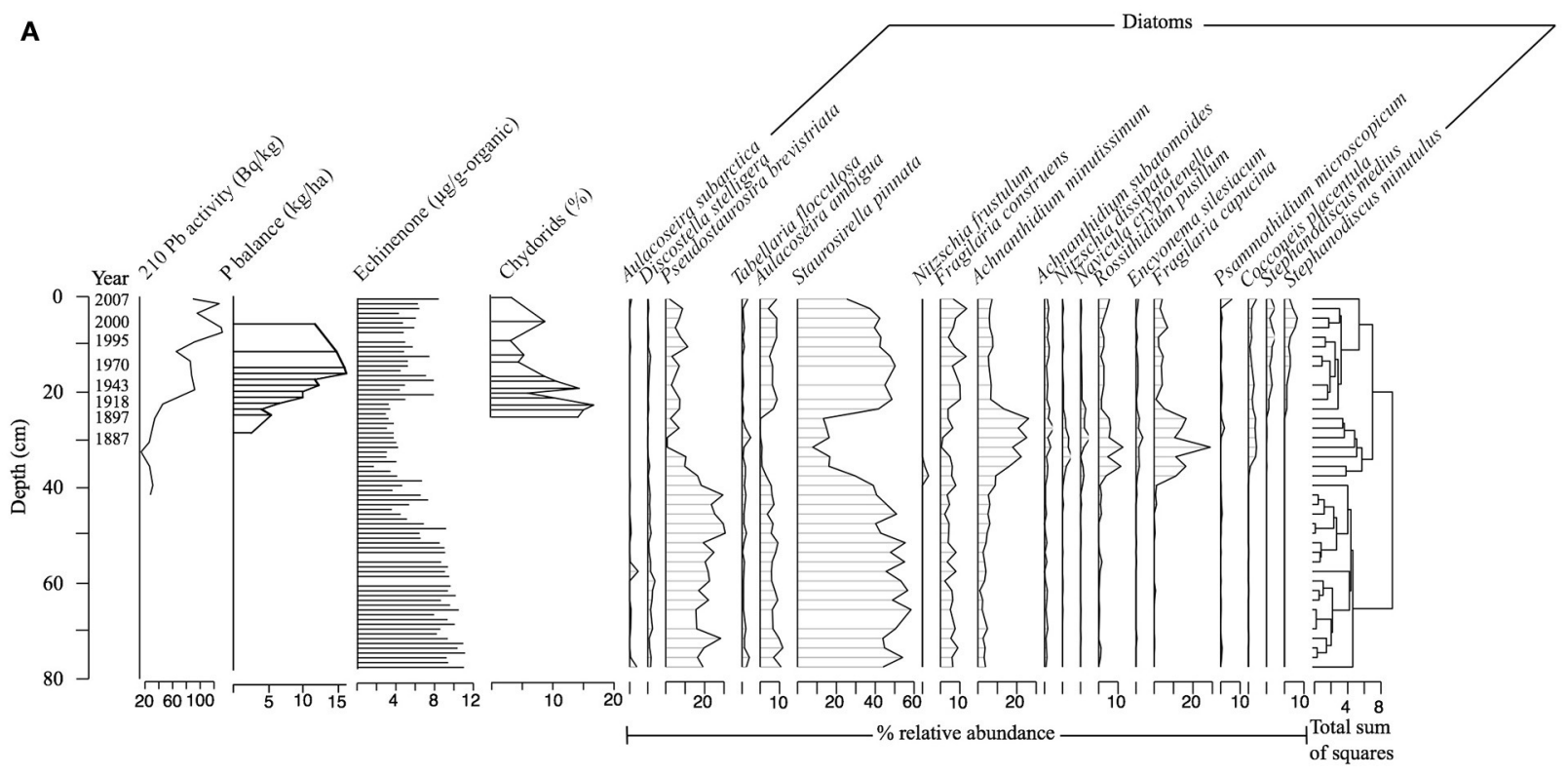

B

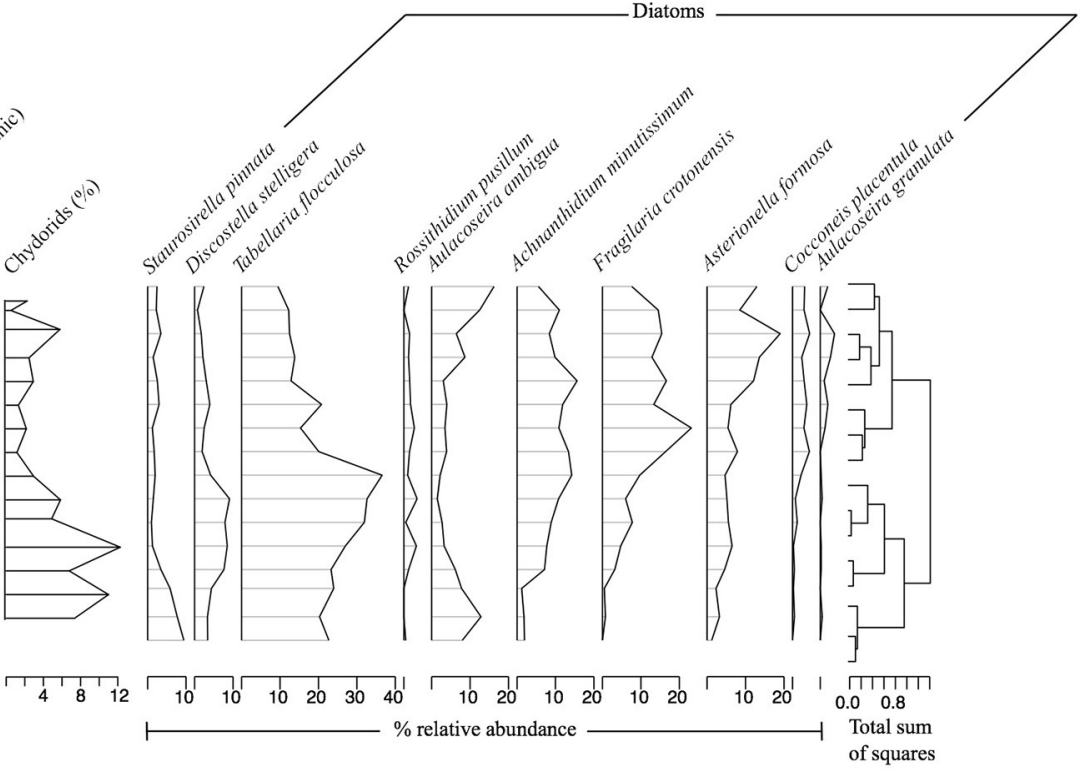

FIGURE 1 | Profiles of dominant diatom taxa (>3\% relative abundance in any one sample), ${ }^{210} \mathrm{~Pb}$ activity (Bq/kg), percent organic matter, echinenone concentrations (ng/g organic matter), and relative abundance of chydorid taxa compared to all cladocera for (A) Petit lac Saint-François (PSF) and (B) Roxton Pond (Roxton). Diatom data are expressed as percent relative abundance. Also shown is the stratigraphically constrained clustering (CONISS) tree based on changes in the diatom assemblage of each lake. 
period, we compared the best model for the response and environmental driver variables along a timeseries. If the two models corresponded to each other (e.g., step-change in response and step-change in driver) an extrinsic regime shift was inferred, whereas if the models did not correspond (e.g., step-change in response and linear increase in driver) an underlying intrinsic regime shift was presumed.

\section{RESULTS}

\section{Historical Changes Inferred from Diatom and Chydorid Records}

The ${ }^{210} \mathrm{~Pb}$ inventories for each sediment core showed that our records spanned at least the last 150 years (Figure 1 and Figure S1). Diatom analysis indicated that PSF Lake was nutrient rich before the industrial era (i.e., pre-1850) with Aulacoseira ambigua and small benthic Fragilaria spp. (sensu lato) dominating the record (Figure 1A). In the midnineteenth century, however, there was a pronounced decrease in the proportion of planktonic diatoms and a shift toward epiphytic taxa that are associated with lower phosphorus conditions (e.g., Achnanthidium minutissimum; Hall and Smol, 1992; Vermaire et al., 2011). This record suggests that PSF transitioned from a historically eutrophic turbid-water state to a clear-water, macrophyte-dominated state. During this clearwater, macrophyte-dominated phase, we noted a corresponding decrease in cyanobacteria pigments, suggesting that this was an ecosystem-wide event. Around 1910, however, the diatom record transitioned back to taxa associated with greater nutrient concentrations, which was also reflected in the loss

\section{A}

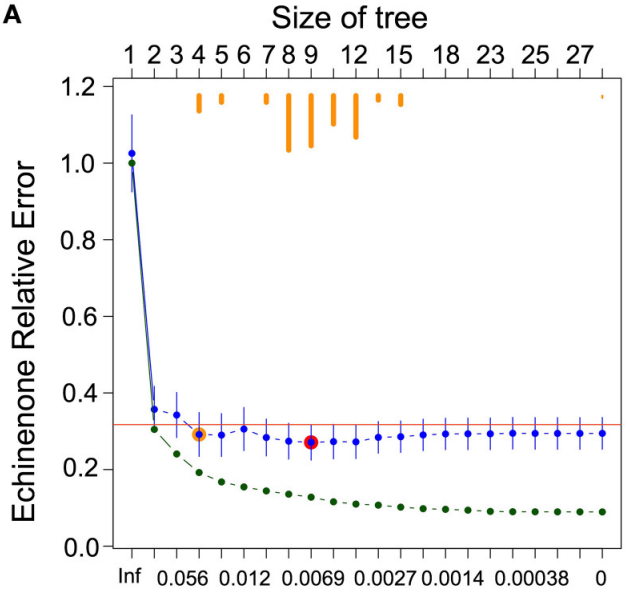

B

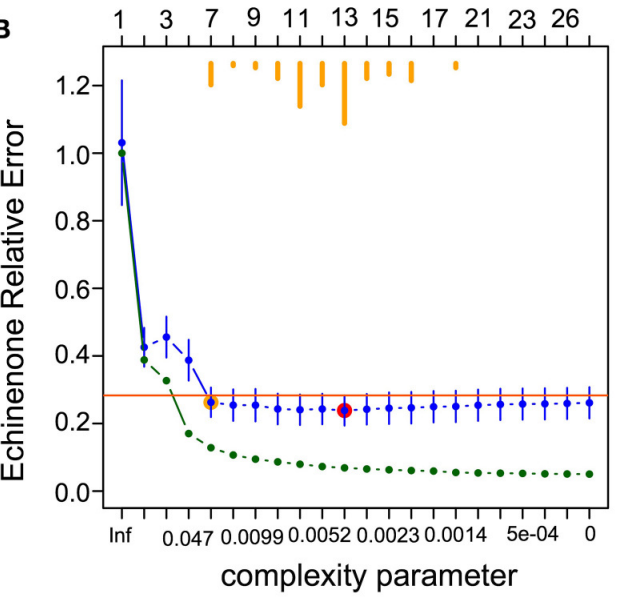

C

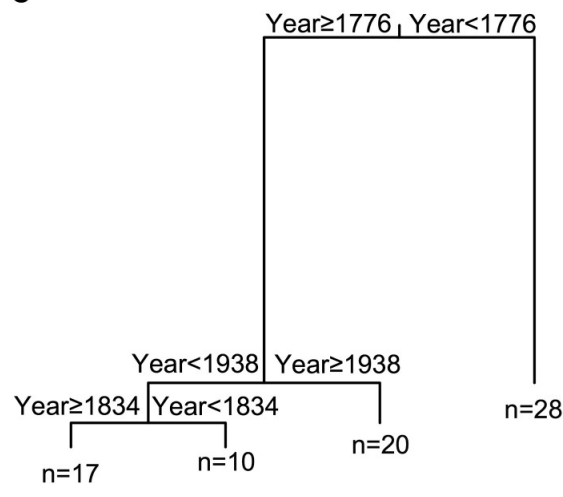

D

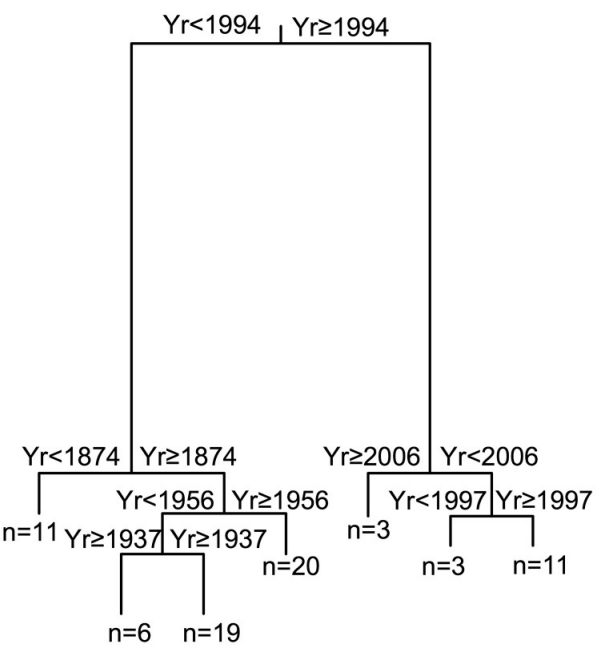

FIGURE 2 | Time-constrained regression tree of cyanobacterial pigment time series (echinenone concentrations). Cross-validation results for (A) Petit Lac St-François and (B) Roxton Pond, where the relative error $\left(R E=1-R^{2}\right)$ of each tree is plotted vs. the complexity parameter. Green points represent the relative error of each tree. Blue points and bars represent the cross-validated relative error and error (1 standard error, SE), respectively. Horizontal orange bars (top) indicate the number of times a particular solution was selected as the best tree during the cross-validation iterations. The tree with the smallest cross-validated relative error is indicated by a red circle over the blue point and the orange point represents the tree located 1 SE above the minimal cross-validated relative error solution (red point). This latter Min +1 SE tree was selected as the most parsimonious tree. Plot of the best tree (pruned using the 1-SE rule), which identified transition points based on year and explained (C) $81 \%$ of the variance for Petit Lac St-François and (D) $87 \%$ of the variance for Roxton Pond. The number of samples (n) in each group are shown at the base of the branch. 
of macrophyte-associated chydorid taxa and an increase in cyanobacteria pigments.

In contrast, Roxton Pond was in a lower-nutrient state before the industrial era (pre-1850). The dominant planktonic (e.g., Discostella stelligera, Tabellaria flocculosa) and benthic diatom taxa (e.g., A. minutissimum) observed in that period are known to be associated with low phosphorus conditions (Hall and Smol, 1992; Dixit et al., 1999; Figure 1B). During this time, macrophyte-associated chydorid taxa were relatively abundant in the bottom half of the core and cyanobacteria concentrations were low, suggesting a clear-water, macrophytedominated state. Following an increase in historical catchment phosphorus loading around 1950, there was a rise in the relative abundance of planktonic diatoms known to be indicative of higher phosphorus conditions (e.g., Fragilaria crotonensis, Aulacoseira ambigua; Hall and Smol, 1992; Dixit et al., 1999) and decline in the relative abundance of chydorid taxa.

\section{Historical Trends in Cyanobacteria}

Regression tree analysis of the echinenone concentration constrained by time suggests four groups for the PSF record and seven for the Roxton Pond record (Figure 2). The trends in echinenone concentration suggest that both PSF and Roxton Pond have undergone abrupt shifts between higher and lower cyanobacteria concentrations (Figure 3). Although there is agreement between the general trends in diatom

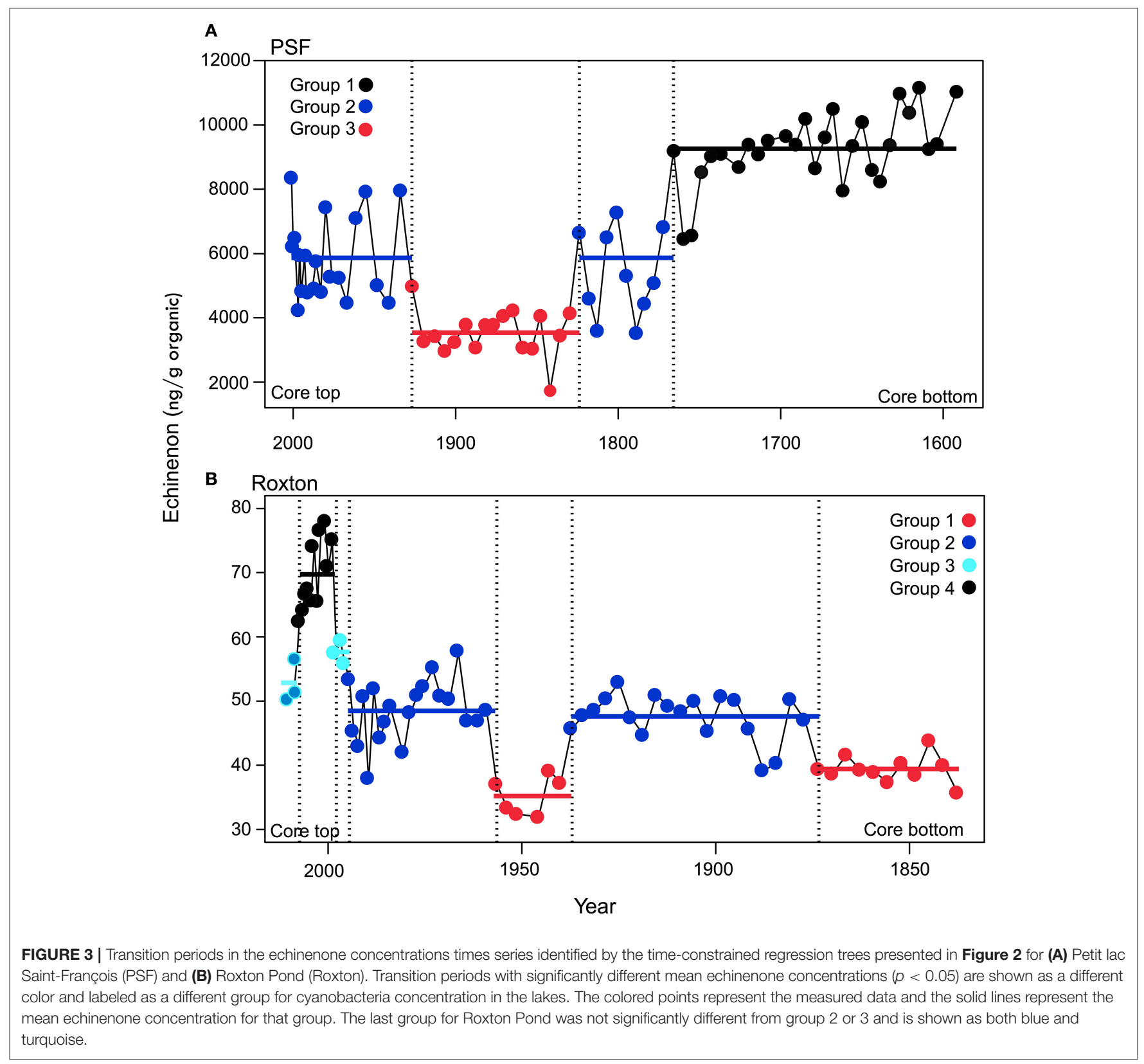


community assemblage and echinenone concentration, the record of echinenone concentration suggests that more shifts have occurred possibly due to the echinenone being analyzed at greater resolution than the diatom samples. Although the regression tree analyses suggest four and seven echinenone groupings for PSF and Roxton Pond, respectively, the ANOVA analyses with subsequent Tukey tests indicate that the lakes have alternated around three (in the case of PSF) or four (in the case of Roxton Pond) cyanobacteria states over their record (Figure 3).

In PSF, four shifts were detected in cyanobacteria concentration. Between ca. 1600 and 1775 PSF was in a very high cyanobacteria regime before transitioning to a moderate cyanobacteria regime between 1775 and 1835 (Figure 3). PSF then underwent a rapid decline in cyanobacteria between 1835 and 1940 before transitioning back to the high cyanobacteria regime between 1940 and 2008. The first three shifts pre-dated our record of environmental time series but the final shift corresponds to a rapid increase in phosphorus loading to the catchment due to agricultural activities.

Similar to PSF, Roxton Pond showed multiple transitions between cyanobacteria groups but followed a more expected pattern transitioning from low cyanobacteria concentrations in the past to higher cyanobacteria concentrations in the latter part of the record. Overall, four distinct cyanobacteria groups were identified in Roxton Pond over the last two centuries (Figure 3). Groups with cyanobacteria minima were observed between the early 1800s to 1875 and from 1935 to 1955 whereas groups with moderate cyanobacteria occurred between 1875 to 1935 and from 1955 to 1995 . In ca. 1995 Roxton Pond transitioned to groupings with greater concentrations of
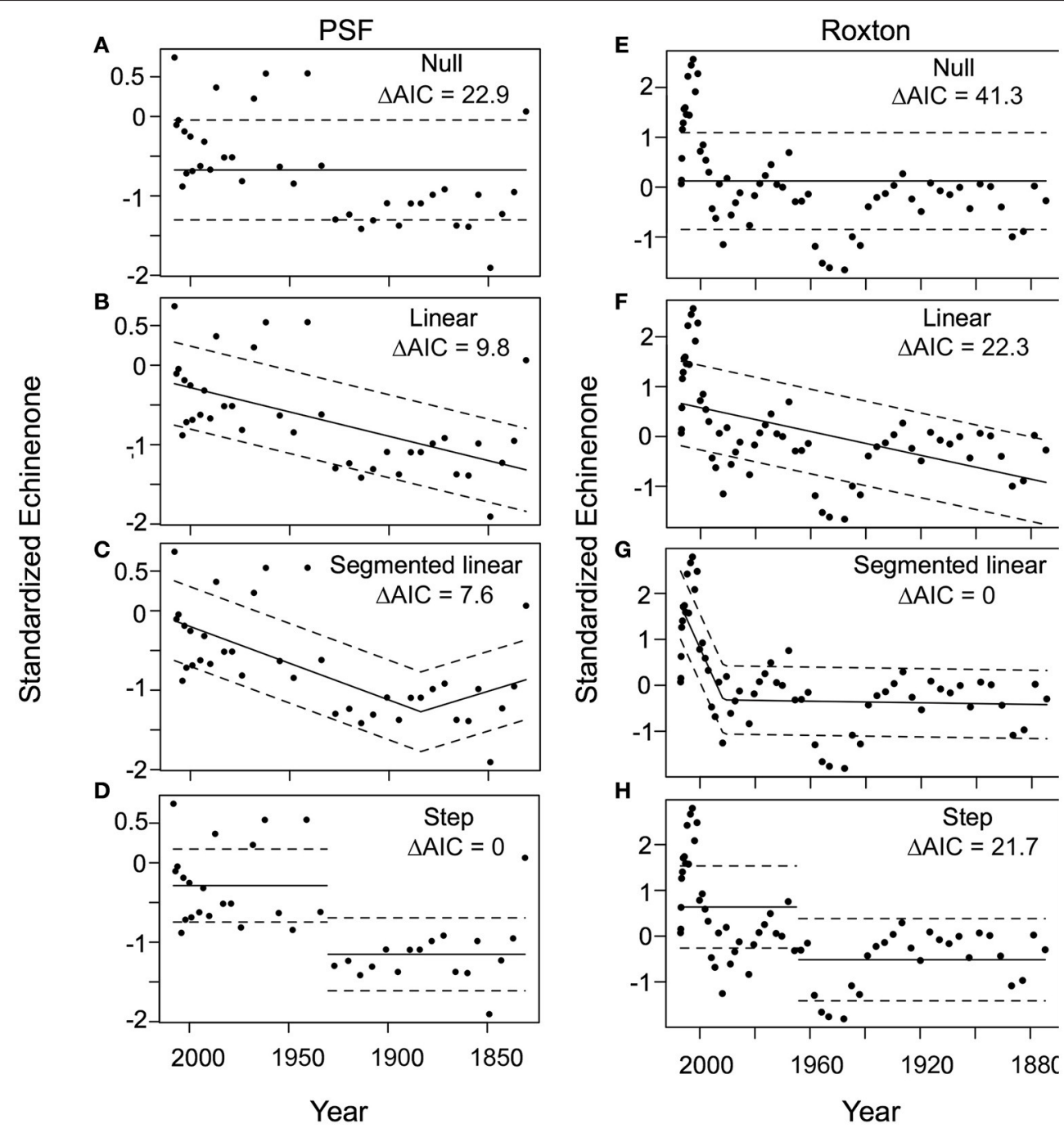

FIGURE 4 | Generalized least squares test for changes in cyanobacteria (echineone concentration) in Petit lac Saint-François (PSF) and Roxton Pond (Roxton). For PSF (A) null, (B) linear, (C) segmented and (D) step and Roxton: (E) null, (F) linear, (G) segmented, (H) step functions were considered as possible models from the mid-1800s to the present. The best model (lowest AIC) corresponds to the step model (D) for PSF and the segmented linear model ( $g$ ) for Roxton. Note that the sigmoidal model did not converge for either PSF or Roxton and is not shown. $\triangle \mathrm{AIC}=$ difference in Akaike information criterion from the best-fit model. 
cyanobacteria reaching a cyanobacteria maxima group between 1995 and 2005, before declining slightly to more moderate cyanobacteria concentrations.

During the transitions in both PSF (post-1900) and Roxton (post-1870) we observed a nonlinear increase in both cyanobacteria concentrations (echinenone pigment) and the P load index. In PSF Lake the cyanobacteria trend was best described by a step function model (Figure 4), whereas changes in the $\mathrm{P}$ load index through time were best described by the segmented model (Figure 5). In Roxton Pond, a segmented linear model best described changes in cyanobacteria concentrations through time with an abrupt increase in the latter part of the record (Figure 4). On the other hand, the historical $\mathrm{P}$ load index for the Roxton Pond catchment was best described by a step function model (Figure 5). Trends in the mean annual temperature data from the Brome weather station were best described by a segmented model and suggests more rapid warming in the region after $\sim 1980$ (Figure 6).

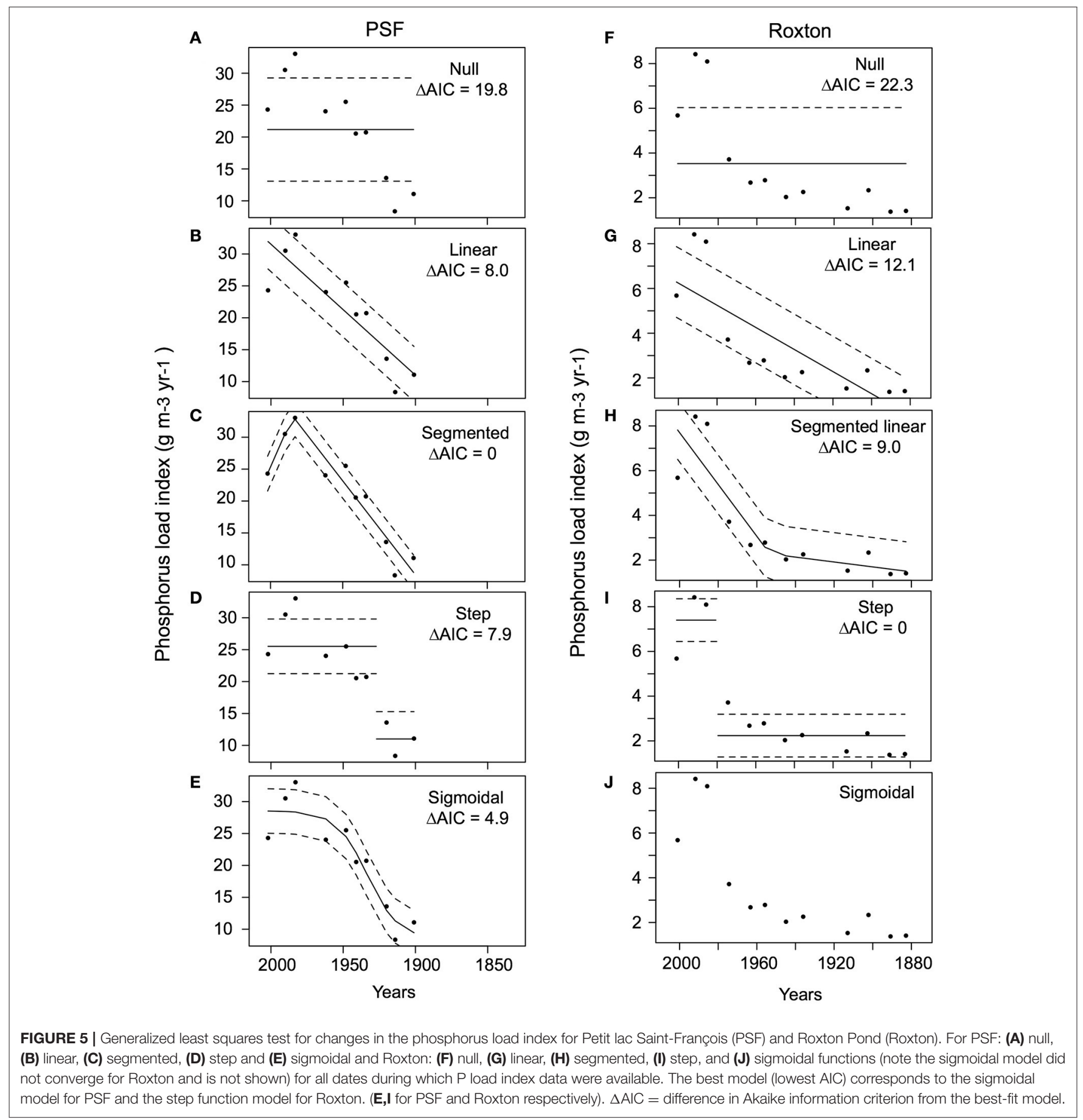


A
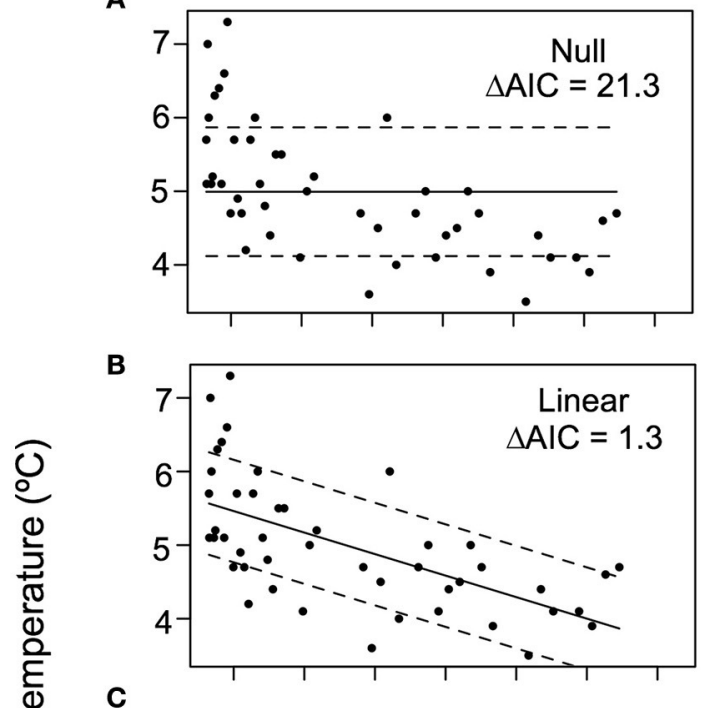

C

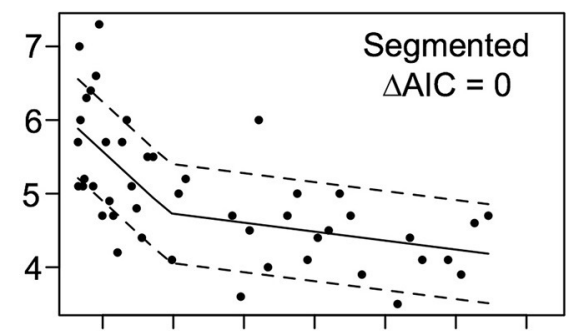

D

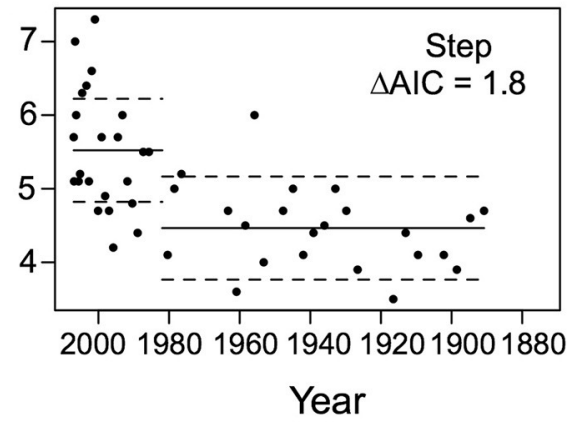

FIGURE 6 | Generalized least squares test for changes in mean annual temperature from the Brome, Quebec weather station based on (A) null, (B) linear, (C) segmented, and (D) step functions (note the sigmoidal model did not converge and is not shown). The best model (lowest AIC) corresponds to the segmented model with a more rapid increase in mean annual temperature occurring after ca. 1980. $\triangle \mathrm{AIC}=$ difference in Akaike information criterion from the best-fit model.

The abrupt, nonlinear increase in cyanobacteria in PSF and Roxton Pond occurred either during a time of linear increase in the environmental drivers in the case of PSF or approximately 10-20 years after abrupt transitions in the environmental drivers in the case of Roxton Pond (Figure 7). In fact, the rapid nonlinear increase in echinenone pigment occurred at Roxton Pond during a time of stabilizing $\mathrm{P}$ load index and linear climate warming trend (Figure 7). These trends suggest that the threshold response of cyanobacteria concentrations in both lakes was driven by intrinsic factors within the ecosystem.

\section{DISCUSSION}

Our analyses revealed pronounced changes in the diatom assemblage and cyanobacteria concentrations in both study lakes. In the latter part of these records, transitions in the sedimentary diatom assemblages and pigment concentrations are related to increases in the catchment phosphorus load index to the lake and climate warming but earlier changes are also evident before data on both drivers were available. PSF Lake underwent a regime shift in response to a gradual increase in the phosphorus load index and temperature, whereas Roxton Pond had a delayed (by over a decade) nonlinear response to catchment $\mathrm{P}$ loading, suggesting factors intrinsic to the ecosystem buffered Roxton Pond until an internal threshold was crossed. Although the records from both lakes support an intrinsic regime shift, the different lags in ecosystem responses suggest that the antecedent conditions of the ecosystems may in part determine their trajectories. In particular, PSF Lake, which had a history of high nutrient and cyanobacteria concentrations before the documented human modification of the catchment, may have had less natural resilience to anthropogenic increases in external phosphorus loading due to its shallower morphology and large catchment to lake volume ratio.

Based on our sedimentary diatom assemblages, we inferred pronounced changes in the water quality of our two study lakes. Prior to the introduction of intensive landscape disturbances (pre-1850), Roxton Pond was a clear-water, macrophytedominated ecosystem. Our sedimentary diatom record from PSF Lake indicates that this lake has undergone shifts in state, however, there is a well-defined transition in the proxy records to the clear-water state that lasted for decades before abruptly transitioning back to eutrophic conditions around $\sim 1940$. The exact cause for the earlier inferred regime shift in the PSF Lake record is difficult to pinpoint without historical data. Nonetheless, the unique morphometry of the PSF basin suggests that it is more sensitive to changes in variables related to nutrient loading relative to Roxton Pond. For example, PSF Lake has a large catchment area to lake area ratio $(\mathrm{CA}: \mathrm{LA}=24)$, which is an established predictor of phosphorus export from catchments (Prairie and Kalff, 1986). Furthermore, shallow lakes with large catchments, such as PSF Lake, are often predicted to be in a mesotrophic or eutrophic state in the absence of human disturbance (Soranno et al., 2008). Therefore, a clear-water state may have been able to establish at PSF Lake at a time when nutrient export to the lake was relatively low, possibly when climate was cooler and when precipitation was lower, relative to the twentieth century (Bradley and Jones, 1993).

Ecosystems can have differing responses to changes in external drivers based on their antecedent conditions or how close they are to a critical threshold (Scheffer and van Nes, 2007; Andersen et al., 2009; Seddon et al., 2016). It is evident that both shallow lakes in this study have undergone abrupt nonlinear increases in cyanobacteria concentrations consistent with the concept of a regime shift. The timing of the nonlinear increases in cyanobacteria concentrations in comparison to the external drivers is consistent with an intrinsic regime shift in both lakes, suggesting that factors internal to the system played 


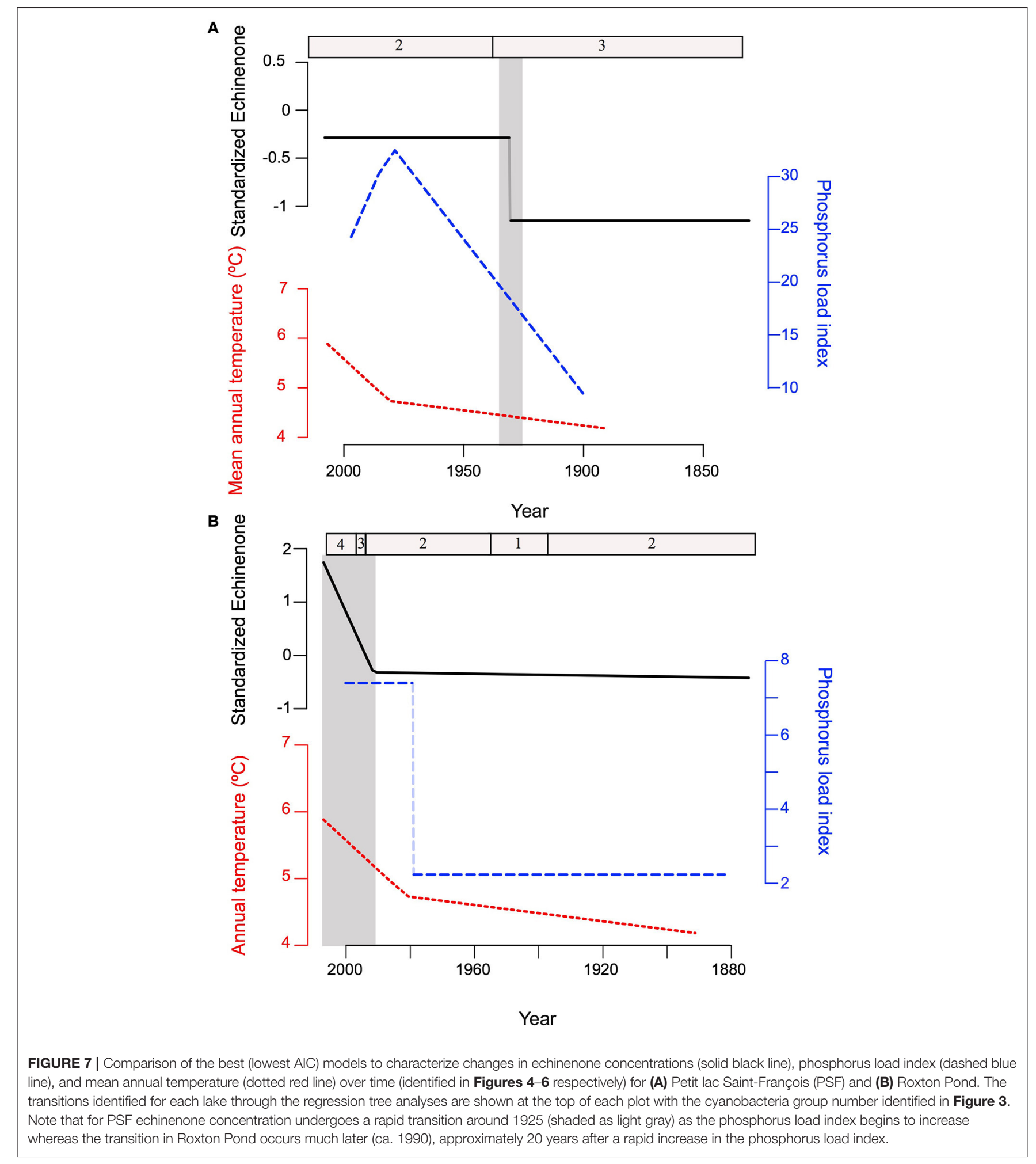

an important role in modulating the ecosystem's response to changes in the drivers, similar to the state threshold model of regime shifts outlined in Andersen et al. (2009) and RandsaluWendrup et al. (2016). Internal factors of the catchment-lake system that may have modulated the ecosystem response to increasing phosphorus loading include adsorption of phosphorus to soil particles that would have slowed phosphorus input into the lakes (Reed-Andersen et al., 2000; Bennett et al., 2001) and 
the ability of macrophyte beds to promote sedimentation and burial of phosphorus even in shallow regions of a lake (Rooney and Kalff, 2003; Rooney et al., 2003).

In this study we examined long-term changes in cyanobacteria concentrations in relation to two well documented external drivers of cyanobacteria concentration in lakes, namely phosphorus loading (Downing et al., 2001) and temperature (Taranu et al., 2015). Other environmental variables could also have influenced the cyanobacterial concentration in shallow lakes and the shift from a clear-water to a turbid-water state (Scheffer and van Nes, 2007). For example, perturbations such as large storm events damaging macrophyte beds (Bachmann et al., 1999) have been linked to a regime shift in Lake Apopka in Florida, although others have disputed this interpretation arguing instead that extensive phosphorus export from the catchment was the primary driver of excessive algae growth in this lake (Lowe et al., 2001). We cannot dismiss the role of other potential perturbations in triggering the nonlinear increase in cyanobacteria in these lakes, however, greater phosphorus inputs and warming temperatures remain dominant and overarching drivers of increased cyanobacterial concentrations in temperate lakes across the globe (Downing et al., 2001; Taranu et al., 2015).

Although, both of our study lakes are inferred to have undergone a regime shift to cyanobacteria dominance in response to human driven increases in external phosphorus loading and increasing mean annual temperatures, other paleolimnological studies of shallow lakes have shown remarkably stable conditions in the face of human modification of their catchments. For example, Karst and Smol (2000) demonstrated that shallow Lake Opinicon in central Ontario displayed relatively little ecological change to human alteration of the catchment even though deeper lakes in the area showed evidence for nutrient enrichment. This is a further example of how the ecosystem response to changes in an external driver depends on the antecedent conditions of that system and how paleolimnological studies can help lake managers better predict ecological outcomes of human disturbance.

Legacy phosphorus accumulation in soils continues to be a major threat to global water quality (Carpenter, 2005; Rowe et al., 2016). In shallow lakes, excess phosphorus flowing into lakes from catchment soils can trigger a regime shift from the preferred clear-water state to the undesirable turbid-water state. Using a combination of paleolimnological methods and long-term historical data for our study region, we have shown that variations in catchment phosphorus balance are related to

\section{REFERENCES}

Andersen, T., Carstensen, J., Hernandez-Garcia, E., and Duarte, C. M. (2009). Ecological thresholds and regime shifts: approaches to identification. Trends Ecol. Evol. 24, 49-57. doi: 10.1016/j.tree.2008.07.014

Appleby, P. G. (2001). "Chronostratigraphic techniques in recent sediments," in Tracking Environmental Change Using Lake Sediments. Basin Analysis, Coring, and Chronological Techniques, eds W. M. Last and J. P. Smol (Dordrecht: Developments in Paleoenvironmental Research, Kluwer Academic Publishers), 171-203. algal dynamics in downstream lakes. In particular, our study suggests that cyanobacteria concentrations increased abruptly in both lakes, however, the timing of this abrupt increase occurred years to decades after the increases in agricultural catchment phosphorus loading and climate warming, consistent with the idea of an intrinsic regime shift. Furthermore, the timing of the cyanobacteria response to the external drivers differed between the lakes, which may be the result of differences in internal factors such as historical trophic state or lake morphometry. Defining critical thresholds for phosphorus loading is an important goal for successful lake management, but the antecedent conditions of the chemical, biological, and physical structure of the lake ecosystem must also be taken into account in order to predict ecosystem response to human disturbance.

\section{AUTHOR CONTRIBUTIONS}

JV, ZT, and IG conceived the project; JV, GM, and KV collected the data, JV and ZT analyzed the data with contributions from GM and EB, JV wrote the manuscript with contributions from ZT, GM, KV, EB, and IG.

\section{FUNDING}

Funding for this work was provided by Natural Sciences and Engineering Research Council of Canada (NSERC) and Fonds québécois de la recherché sur la nature et les technologies (FQRNT). This study is a contribution to the FQRNTfunded Groupe de Recherche Interuniversitaire en Limnology (GRIL).

\section{ACKNOWLEDGMENTS}

We would like to thank L. McGruthers, M. Richard Albert, and E. Brown who helped with the fieldwork and Dr. Pierre Legendre and Dr. Alistair Seddon who provided statistical advice and help with $\mathrm{R}$ code. A special thank you to E. Brown for her help counting the PSF diatom record and M. Richard Albert and K. Simpson for providing the zooplankton and cyanobacteria pigment data for PSF Lake.

\section{SUPPLEMENTARY MATERIAL}

The Supplementary Material for this article can be found online at: https://www.frontiersin.org/articles/10.3389/fevo. 2017.00146/full\#supplementary-material

Bachmann, R. W., Horsburgh, C. A., Hoyer, M. V., Mataraza, L. K., and Canfield, D. E. Jr. (2002). Relations between trophic state indicators and plant biomass in Florida lakes. Hydrobiologia 470, 219-234. doi: 10.1023/A:1015660922494

Bachmann, R. W., Hoyer, M. V., and Canfield, D. E. Jr. (1999). The restoration of Lake Apopka in relation to alternative stable states. Hydrobiologia 394, 219-232. doi: 10.1023/A:1003638329772

Battarbee, R. W., Jones, V. J., Flower, R. J., Cameron, N. G., Bennion, H., Carvalho, L., et al. (2001). Developments in Paleoenvironmental Research: Tracking Environmental Change Using Lake Sediments, Vol. 3. (Dordrecht: Kluwer Academic Publishers). 
Bayley, S. E., Creed, I. F., Sass, G. Z., and Wong, A. S. (2007). Frequent regime shifts in trophic states in shallow lakes on the Boreal Plain: alternative "unstable" states? Limnol. Oceanogr. 52, 2002-2012. doi: 10.4319/lo.2007.52.5.2002

Bennett, E. M., Carpenter, S. R., and Caraco, N. F. (2001). Human impact on erodable phosphorus and eutrophication: a global perspective: increasing accumulation of phosphorus in soil threatens rivers, lakes, and coastal oceans with eutrophication. Bioscience 51, 227-234. doi: 10.4319/lo.2008.53.2.0773

Biggs, R., Carpenter, S. R., and Brock, W. A. (2009). Turning back from the brink: detecting an impending regime shift in time to avert it. Proc. Nat. Acad. Sci. U.S.A. 106, 826-831. doi: 10.1073/pnas.0811729106

Bradley, R. S., and Jones, P. D. (1993). 'Little Ice Age' summer temperature variations: their nature and relevance to recent global warming trends. Holocene 3, 367-376. doi: 10.1177/095968369300300409

Carpenter, S. R. (2005). Eutrophication of aquatic ecosystems: bistability and soil phosphorus. Proc. Natl. Acad. Sci. U.S.A. 102, 10002-10005. doi: 10.1073/pnas.0503959102

Carpenter, S. R., and Brock, W. A. (2006). Rising variance: a leading indicator of ecological transition. Ecol. Lett. 9, 311-318. doi: 10.1111/j.1461-0248.2005.00877.x

Cumming, B. F., Wilson, S. E., Hall, R. I., and Smol, J. P. (1995). Diatoms from British Columbia (Canada) Lakes and Their Relationship to Salinity, Nutrients and Other Limnological Variables, Bibliotheca Diatomologica Band 31, ed H. Lange-Bertalot Berlin: J. Cramer.

De'ath, G. (2002). Multivariate regression trees: a new technique for modeling species-environment relationships. Ecology 83, 1105-1117. doi: 10.1890/00129658(2002)083[1105:MRTANT]2.0.CO;2

deYoung, B., Barange, M., Beaugrand, G., Harris, R., Perry, R. I., Scheffer, M., et al. (2008). Regime shifts in marine ecosystems: detection, prediction and management. Trends Ecol. Evol. 23, 402-409. doi: 10.1016/j.tree.2008. 03.008

Dixit, S. S., Smol, J. P., Charles, D. F., Hughes, R. M., Paulsen, S. G., and Collins, G. B. (1999). Assessing water quality changes in the lakes of the northeastern United States using sediment diatoms. Can. J. Fish. Aquat. Sci. 56, 131-152. doi: 10.1139/f98-148

Downing, J. A., Watson, S. B., and McCauley, E. (2001). Predicting cyanobacteria dominance in lakes. Can. J. Fish. Aquat. Sci. 58, 1905-1908. doi: $10.1139 /$ f01-143

Fallu, M.-A., Allaire, N., and Pienitz, R. (2000). Freshwater Diatoms from Northern Québec and Labrador (Canada): Species-Environment Relationships in Lakes of Boreal Forest, Forest-Tundra and Tundra Regions. Bibliotheca Diatomologica Band 45, eds H. Lange-Bertalot and P. Kociolek. J. Cramer (Berlin).

Foley, J. A., Coe, M. T., Scheffer, M., and Wang, G. (2003). Regime shifts in the Sahara and the Sahel: interactions between ecological and Climatic Systems in northern Africa. Ecosystems 6, 524-539. doi: 10.1007/s10021-002-0227-0

Giani, A., Bird, D. F., Prairie, Y. T., and Lawrence, J. F. (2005). Empirical study of cyanobacterial toxicity along a trophic gradient of lakes. Can. J. Fish. Aquat. Sci. 62, 2100-2109. doi: 10.1139/f05-124

Glew, J. R. (1989). A new trigger mechanism for sediment samplers. J. Paleolimnol. 2, 241-243. doi: 10.1007/BF00195474

Grimm, E. C. (1987). CONISS: a FORTRAN 77 program for stratigraphically constrained cluster analysis by the method of incremental sum of squares. Comput. Geosci. 13, 13-35. doi: 10.1016/0098-3004(87)90022-7

Groffman, P. M., Baron, J. S., Blett, T., Gold, A. J., Goodman, I., Gunderson, L. H., et al. (2006). Ecological thresholds: the key to successful management or an important concept with no practical application? Ecosystems 9, 1-13. doi: 10.1007/s10021-003-0142-z

Hall, R. I., and Smol, J. P. (1992). A weighted-averaging regression and calibration model for inferring total phosphorus concentrations from diatoms in British Columbia (Canada) lakes. Freshwater Biol. 27, 417-434. doi: 10.1111/j.1365-2427.1992.tb00551.x

Holling, C. S. (1973). Resilience and stability of ecological systems. Annu. Rev. Ecol. Syst. 4, 1-23. doi: 10.1146/annurev.es.04.110173.000245

Jeppesen, E., Jensen, J. P., Søndergaard, M., and Lauridsen, T. (1999). Trophic dynamics in turbid and clearwater lakes with special emphasis on the role of zooplankton for water clarity. Hydrobiologia 408/409, 217-231. doi: 10.1023/A:1017071600486

Juggins, S. (2016). rioja: Analysis of Quaternary Science Data. R package version 0.5-6. Available online at: http://cran.r-project.org/package=rioja.
Karst, T., and Smol, J. P. (2000). Paleolimnological evidence of limnetic nutrient concentration equilibrium in a shallow, macrophyte-dominated lake. J. Aquat. Sci. 62, 20-38. doi: 10.1007/s000270050073

Korhola, A., and Rautio, M. (2001). "Cladocera and other branchiopod crustaceans," in Developments in Paleoenvironmental Research: Tracking Environmental Change Using Lake Sediments Volume 4: Zoological Indicators, eds W. M. Last and J. P. Smol (Dordrecht: Kluwer Academic Publishers), 5-41.

Krammer, K., and Lange-Bertalot, H. (2004). Süßwasserflora von Mitteleuropa. Stuttgart: Elsevier.

Leavitt, P. R., and Hodgson, D. A. (2001). "Sedimentary pigments" in Developments in Paleoenvironmental Research: Tracking Environmental Change Using Lake Sediments Volume 3, eds W. M. Last and J. P. Smol (Dordrecht: Kluwer Academic Publishers), 295-325.

Legendre, P., and Legendre, L. (2012). Numerical Ecology, Vol. 24, 3rd Edn. Amsterdam: Elsevier.

Lévesque, B., Gervais, M. C., Chevalier, P., Gauvin, D., Anassour-Laouan-Sidi, E., Gingras, S., et al. (2014). Prospective study of acute health effects in relation to exposure to cyanobacteria. Sci. Total Environ. 466-467, 397-403. doi: 10.1016/j.scitotenv.2013.07.045

Lowe, E. F., Battoe, L. E., Coveney, M. F., Schelske, C. L., Havens, K. E., Erich, R. et al. (2001). The restoration of Lake Apopka in relation to alternative stable states: an alternative view to that of Bachmann et al. (1999). Hydrobiologia 448 , 11-18. doi: 10.1023/A:1017541010768

MacDonald, G. K., and Bennett, E. (2009). Phosphorus accumulation in Saint Lawrence River watershed soils: a century-long perspective. Ecosystems 12, 621-635. doi: 10.1007/s10021-009-9246-4

McGowan, S., Leavitt, P. R., Hall, R. I., Anderson, N. J., Jeppesen, E., and Odgaard, B. V. (2005).Controls of algal abundance and community composition during ecosystem state change. Ecology 86, 2200-2211. doi: 10.1890/04-1029

Monchamp, M.-E., Pick, F. R., Beisner, B. E., and Maranger, R. (2014). Nitrogen forms influence microcystin concentration and composition via changes in cyanobacterial community structure. PLoS ONE 9:e85573. doi: 10.1371/journal.pone.0085573

Ouellette, M.-H., and Legendre, P. (2013). MVPARTwrap: Additional Features for Package mvpart. R package, version 0.1-9.2. Available online at: https://cran. rproject.org/src/contrib/Archive/MVPARTwrap/

Prairie, Y. T., and Kalff, J. (1986). Effect of catchment size on phosphorus export. Water Resour. Bull. 22, 465-470. doi: 10.1111/j.1752-1688.1986.tb01901.x

Randsalu-Wendrup, L., Conley, D. J., Carstensen, J., and Fritz, S. C. (2016). Paleolimnological records of regime shifts in lakes in response to climate change and anthropogenic activities. J. Paleolimnol. 56, 1-14. doi: 10.1007/s10933-016-9884-4

R Development Core Team (2016). R: A Language and Environment for Statistical Computing. Vienna: R Foundation for Statistical Computing. Available online at: http://www.R-project.org.

Reed-Andersen, T., Carpenter, S. R., and Lathrop, R. C. (2000). Phosphorus flow in a watershed-lake ecosystem. Ecosystems 3, 561-573. doi: 10.1007/s100210000049

Richard Albert, M. A., Chen, G., MacDonald, G. K., Vermaire, J. C., Bennett, E. M., and Gregory-Eaves, I. (2010). Phosphorus and land-use changes are significant drivers of cladoceran community composition and diversity: an analysis over spatial and temporal scales. Can. J. Fish. Aquat. Sci. 67, 1262-1273. doi: 10.1139/F10-058

Rooney, N., and Kalff, J. (2003). Submerged macrophyte-bed effects on watercolumn phosphorus, chlorophyll a, and bacterial production. Ecosystems 6, 797-807. doi: 10.1007/s10021-003-0184-2

Rooney, N., Kalff, J., and Habel, C. (2003). The role of submerged macrophyte beds in phosphorus and sediment accumulation in Lake Memphremagog, Quebec, Canada. Limnol. Oceanogr. 48: 1927-1937. doi: 10.4319/lo.2003.48. 5.1927

Rowe, H., Withers, P. J. A., Baas, P., Chan, N. I., Doody, D., Holiman, J., et al. (2016). Integrating legacy soil phosphorus into sustainable nutrient management strategies for future food, bioenergy and water security. Nutri. Cycl. Agroecosyst. 104, 393-412. doi: 10.1007/s10705-015-9726-1

Sayer, C. D., Burgess, A., Kari, K., Davidson, T. A., Peglar, S., Yang, H., et al. (2010). Long-term dynamics of submerged macrophytes and algae in a small and shallow, eutrophic lake: implications for the stability of macrophytedominance. Freshwat. Biol. 55, 565-583. doi: 10.1111/j.1365-2427.2009.02353.x 
Scheffer, M. (1990). Multiplicity of stable states in freshwater systems. Hydrobiologia 200/201, 475-486. doi: 10.1007/BF02530365

Scheffer, M. (2004). Ecology of Shallow Lakes. Dordrecht: Kluwer Academic.

Scheffer, M., Bascompte, J., Brock, W. A., Brovkin, V., Carpenter, S. R., Dakos, V., et al. (2009). Early-warning signals for critical transitions. Nature 461, 53-59. doi: $10.1038 /$ nature 08227

Scheffer, M., and van Nes, E. H. (2007). Shallow lakes theory revisited: various alternative regimes driven by climate, nutrients, depth and lake size. Hydrobiologia 584, 455-466. doi: 10.1007/s10750-007-0616-7

Seddon, A. W. R., Froyd, C. A., Witkowski, A., and Willis, K. J. (2014). A quantitative framework for analysis of regime shifts in a Galápagos coastal lagoon. Ecology 95, 3046-3055. doi: 10.1890/13-1974.1

Seddon, A. W. R.,Macias-Fauria, M., Long, P. R., Benz, D., and Willis, K. J. (2016). Sensitivity of global terrestrial ecosystems to climate variability. Nature 531, 229-232. doi: 10.1038/nature16986

Shaw Chraibi, V. L., Bennett, E. M., and Gregory-Eaves, I. (2011). Lake memphrémagog: a paleolimnological and environmental policy case study. Lake Reserv. Manag. 27, 355-364.

Smol, J. P., Wolfe, A. P., Birks, H. J. B., Douglas, M. S. V., Jones, V. J., Korhola, A., et al. (2005). Climate-driven regime shifts in the biological communities of arctic lakes. Proc. Natl. Acad. Sci. U.S.A. 102, 4397-4402. doi: 10.1073/pnas.0500245102

Soranno, P. A., Cheruvelil, K. S., Stevenson, R. J., Rollins, S. L., Holden, S. W., Heaton, S., et al. (2008). A framework for developing ecosystem-specific nutrient criteria: Integrating biological thresholds with predictive modeling. Limnol. Oceanogr. 53, 773-787. doi: 10.2307/40006458

Taranu, Z. E., Gregory-Eaves, I., Leavitt, P. R., Bunting, L., Buchaca, T., Catalan, J., et al. (2015). Acceleration of cyanobacterial dominance in north temperate-subarctic lakes during the Anthropocene. Ecol. Lett. 18, 375-384. doi: 10.1111/ele.12420

Therneau, T. M., Atkinson, B., and De'ath, G. (2014). mvpart: Multivariate Partitioning. R package, version 1.6-2. Available online at: https://cran.rproject.org/src/contrib/Archive/mvpart/

Velghe, K., Vermaire, J. C., and Gregory-Eaves, I. (2012). Declines in littoral species richness across both spatial and temporal nutrient gradients: a palaeolimnological study of two taxonomic groups. Freshwater Biol. 57, 2378-2389. doi: 10.1111/fwb.12017
Vermaire, J. C., and Gregory-Eaves, I. (2008). Reconstructing changes in macrophyte cover in lakes across the northeastern United States based on sedimentary diatom assemblages. J. Paleolimnol. 39, 477-490. doi: 10.1007/s10933-007-9125-y

Vermaire, J. C., Prairie, Y. T., and Gregory-Eaves, I. (2011). The influence of submerged macrophytes on sedimentary diatom assemblages. J. Phycol. 47, 1230-1240. doi: 10.1111/j.1529-8817.2011.01069.x

Vermaire, J. C., Prairie, Y. T., and Gregory-Eaves, I. (2012). Diatom-inferred decline of macrophyte abundance in lakes of southern Quebec, Canada. Can. J. Fis. Aquat. Sci. 69, 511-524. doi: 10.1139/f2011-169

Vincent, L. A., Wang, X. L., Milewska, E. J., Wan, H., Yang, F., and Swail, V. (2012). A second generation of homogenized Canadian monthly surface air temperature for climate trend analysis. J. Geophys. Res. 117:D18110. doi: 10.1029/2012JD017859

Wang, R., Dearing, J. A., Langdon, P. G., Zhang, E., Yang, X., Dakos, V., et al. (2012). Flickering gives early warning signals of a critical transition to a eutrophic lake state. Nature 492, 419-422. doi: 10.1038/nature11655

Williams, J. W., Blois, J. L., and Shuman, B. N. (2011). Extrinsic and intrinsic forcing of abrupt ecological change: case studies from the late Quaternary. J. Ecol. 99, 664-677. doi: 10.1111/j.1365-2745.2011. 01810.x

Zapata, M., Rodriguez, F., and Garrido, J. L. (2000). Separation of chlorophylls and carotenoids from marine phytoplankton: a new HPLC method using a reversed phase $\mathrm{C}_{8}$ column and pyridine-containing mobile phases. Mar. Ecol. Prog. Ser. 195, 29-45. doi: 10.3354/meps195029

Conflict of Interest Statement: The authors declare that the research was conducted in the absence of any commercial or financial relationships that could be construed as a potential conflict of interest.

Copyright (c) 2017 Vermaire, Taranu, MacDonald, Velghe, Bennett and GregoryEaves. This is an open-access article distributed under the terms of the Creative Commons Attribution License (CC BY). The use, distribution or reproduction in other forums is permitted, provided the original author(s) or licensor are credited and that the original publication in this journal is cited, in accordance with accepted academic practice. No use, distribution or reproduction is permitted which does not comply with these terms. 